


\section{Editorial Committee}

Su-Hie TING

Ai-Ping $\mathrm{HO}$

Collin JEROME

Hamidah ABDUL WAHAB

Wan Robiah MEOR OSMAN

Wun-Chiew PUNG

Cover Design: Nur Shazwanie WAKIMIN

(C) 2021 Universiti Malaysia Sarawak

94300 Kota Samarahan

Sarawak, Malaysia

All rights reserved; no part of this publication may be reproduced, stored or transmitted in any form or by any means without prior written permission of the copyright holder.

The proceedings have been edited for format and layout, but content and language errors remain the responsibility of the author(s). The proceedings is not refereed. Papers which fall too far from specified requirements could not be included in the proceedings. For further details, visit http://www.conference.unimas.my/2021/icls2021/

The proceedings are available at http://www.conference.unimas.my/2021/icls2021/index.php/programme/icl s2021-proceedings

- Associate Professor Dr Su-Hie Ting -

National Library of Malaysia Cataloguing in Publication Data

e ISBN 978-967-2298-69-4

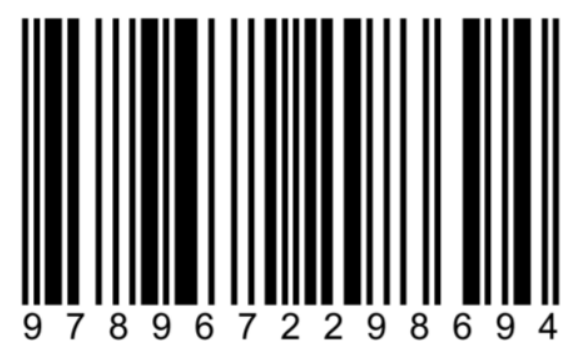




\title{
PANDEMIK COVID-19 MEMPERKAYA AKRONIM BAHASA MELAYU
}

\author{
Mary Fatimah SUBET*1, \\ Roslan ALI ${ }^{2}$ \\ Salbia HASSAN ${ }^{3}$ \\ Dayang Sariah ABANG SUHAI ${ }^{4}$ \\ Muhammad Zaid DAUD ${ }^{5}$ \\ Shahira JOHAN ${ }^{6}$ \\ 1,2,3,4,5 Universiti Malaysia Sarawak, Sarawak, Malaysia \\ ${ }^{6}$ Universiti Islam Antarabangsa, Kuala Lumpur, Malaysia \\ 1.sufatimah@unimas.my \\ 2aroslan@unimas.my \\ 3hsalbia@unimas.my \\ 4asdsariah@unimas.my \\ 5zaid daud93@yahoo.com \\ 6shahira.j97@gmail.com
}

*Corresponding author

\section{ABSTRAK}

Beberapa akronim terkini telah wujud apabila dunia dilanda pandemik COVID-19. Kajian ini bertujuan untuk mengesan dan mengetengahkan beberapa akronim baharu dalam bentuk singkatan yang muncul dalam usaha Kerajaan Malaysia membendung penularan COVID-19. Kajian ini ialah kajian kualitatif menggunakan kerangka pengkategorian akronim yang telah dikemukakan oleh Nik Safiah Karim et.al (2014). Data diperoleh melalui mesej pesanan ringkas (SMS) pihak Majlis Keselamatan Negara (MKN) Malaysia. Sebanyak 200 kongsian maklumat SMS kepada umum daripada pihak MKN antara 30 April 2020 hingga 26 Mei 2021 kepada pengguna talian telco dianalisis di samping kaedah pemerhatian informasi di laman sesawang dan kongsian siaran berita terpilih turut dilakukan untuk mengenal pasti data kajian yang mengandungi akronim. Seterusnya borang soal selidik dirangka untuk melengkapkan dapatan kajian. 152 orang responden telah terlibat menjawab soal selidik ini atas talian. Dapatan kajian menunjukkan terdapat akronim popular seperti PKP, PKBP, PKPD, SOP, 3S, 3W, 3C dan beberapa lagi berkaitan COVID-19 yang telah berakar kukuh dalam ujaran bahasa seharian masyarakat Malaysia dalam membicarakan pandemik COVID-19. Akronim-akronim ini yang sekarang didapati digunakan secara meluas diharap dapat memperkaya dan menambah akronim sedia ada dalam Bahasa Melayu.

Kata Kunci: COVID-19;,akronim;,Bahasa Melayu;,mesej pesanan ringkas (SMS) 


\title{
COVID-19 PANDEMIC ENRICHES ACRONYMS IN MALAY LANGUAGE
}

\begin{abstract}
Several new acronyms in the form of abbreviations exist when the world was hit by the COVID-19 pandemic. This study aims to detect and highlight some new acronyms that have emerged alongside the Malaysian Government's efforts to curb the spreading of COVID-19 since its outbreak. This study is a qualitative study using the acronym categorization framework by Nik Safiah Karim (2014). Data was obtained via short message service (SMS) from Malaysia National Security Council (MKN/NSC). A total of 200 SMS shared to the public from the NSC between 30 April 2020 to 26 May 2021 to TELCO users were analyzed. Observations on information shared on chosen websites, and news channels were also carried out. To complete the findings, an online questionnaire was designed. 150 respondents were involved in completing this questionnaire. The findings of the study show that there are now popular acronyms associated with COVID-19 such as PKP, PKBP, PKPD, SOP, 3S, etc that have been firmly rooted in the everyday language of Malaysian society in addressing COVID-19 pandemic. These acronyms are now widely used, and as such it is hope that these acronyms will enrich and supplement existing acronyms in Malay Language.
\end{abstract}

Keywords: COVID-19;,acronym;,Malay Language;,short message service (SMS)

\section{Pengenalan}

Pada penghujung tahun 2019, penduduk Wuhan di China digemparkan dengan penularan penyakit baharu - COVID-19 yang menyerang sistem pernafasan manusia. Sejak itu, COVID-19 telah ada dalam komuniti. Pada mulanya, COVID-19 cuma berstatus wabak sahaja dan dikenali sebagai Novel Coronavirus (2019-nCoV), namun selepas itu, wabak ini merebak dengan sangat aktif sehingga pihak Pertubuhan Kesihatan Sedunia (WHO) mengkategorikannya sebagai pandemik COVID-19 sebab telah tersebar melepasi sempadan dunia. Menurut Baharudin, R., Kasdan, J., \& Shamsuri, A. S. (2020), istilah COVID-19 ini adalah berdasarkan kependekan bagi kata Coronavirus Disease 2019. Kajian ini pula mengemukakan dan memurnikan dengan lebih lanjut kependekan yang dimaksudkan ini. COVID- 19 diwujudkan dengan menggunakan gabungan akronim suku kata dan huruf dalam perkataan iaitu "CO" daripada suku kata pertama "Coronavirus Disease 2019" (seperti yang digariskan) , "VI" daripada suku kata keempat "Coronavirus Disease 2019" (seperti yang digariskan) dan "D" daripada perkataan kedua, suku kata pertama kata "Disease" (seperti yang digariskan). Angka "19" pula adalah daripada kebiasaan singkatan angka bagi tahun tercetusnya pandemik ini iaitu 2019 yang disingkatkan kepada angka "19" sahaja, dan tanda sempang sebagai cara penulisan untuk gabungan perkataan dan angka. Maka, akronim COVID-19 telah dikenali seantero dunia. Selain pewujudan istilah COVID-19 ini, kemunculannya juga telah menyebabkan munculnya kata-kata dalam kumpulan akronim yang berkaitan dengan COVID-19 ini yang-wujud seperti cendawan tumbuh selepas hujan, yang disingkatkan atau digabungkan daripada suku kata atau huruf-huruf tertentu dalam penciptaan akronim. 
Perbezaan pemahaman tentang akronim dalam kalangan tokoh/pakar bahasa dan atas sebab, akronim sebagai salah satu pembentukan kata dalam bahasa Melayu yang tidak pernah mendapat kata sepakat daripada tokoh/pakar/ahli bahasa kerana tidak berdasarkan prinsip yang jelas dan agak longgar dianggap sebagai satu kelompangan dalam kajian ini. Kesalahfahaman atau kekeliruan tentang akronim dan singkatan dapat difahami dengan baik apabila kita mengikut rumus-rumus tatabahasa pegangan. Kajian ini mengetengahkan bahawa ciri-ciri akronim ada 4, iaitu ditulis dan disebut sebagai satu perkataan yang utuh, dapat mengekalkan makna pada rangkai kata asalnya, berfungsi untuk memendekkan sebutan dan membentuk perkataan tunggal.

\section{Metodologi}

Kajian ini merupakan kajian kualitatif, menggunakan kaedah analisis teks (teks pesanan ringkas (SMS) yang disalurkan melalui pelbagai talian telco di Malaysia seperti Celcom, Maxis, Digi, dan sebagainya, (dalam konteks kajian ini, data diambil daripada SMS yang disalurkan oleh pihak MKN kepada pengguna talian Celcom) dan pemerhatian. Kebanyakan data juga diteliti daripada maklumat bahan primary dan sekunder yang berkaitan dengan pandemik COVID-19. Maklumat-maklumat yang diperoleh adalah daripada pelbagai sumber sahih seperti buku, jurnal, dan artikel ilmiah. Maklumanmakluman sahih daripada laman-laman web/sesawang rasmi milik agensi-agensi kerajaan di Malaysia, khususnya MKN dan laman sesawang Kementerian Kesihatan Malaysia (KKM), pihak Berkuasa Tempatan (PBT) dan pelbagai agensi lain yang berkaitan juga diteliti seperti siaran berita yang disiarkan oleh pihak Radio Televisyen Malaysia (RTM), dan saluran berita TV3 turut diteliti. Data-data kajian telah dianalisis menggunakan kerangka definisi akronim yang dikemukakan menggunakan kerangka pengkategorian akronim yang telah dikemukakan oleh Nik Safiah Karim, Farid M.Onn, Hashim Hj.Musa dan Abdul Hamid Mahmood (2014) yang menyatakan bahawa akronim ialah kata singkatan yang terbentuk dengan menggabungkan huruf awal suku kata atau gabungan kombinasi huruf awal dan suku kata daripada satu rangkai kata, dan ditulis serta dilafazkan sebagai kata yang wajar.

\section{Analisis Dan Perbincangan}

Pandemik COVID-19 telah menyaksikan pelbagai akronim baharu yang kebanyakannya dalam bentuk singkatan (berdasarkan pengertian yang dikemukakan dalam kajian ini setelah mengesan kelompangan yang ada dalam definisi-definisi sebelumnya) tercipta dalam jangka masa yang singkat. Terdapat penggunaan rangkai-rangkai kata serta ayat yang mewujudkan penyebutan semula dalam bentuk akronim yang rata-rata didapati berbentuk singkatan. Kajian ini mendapati akronim-akronim ini diguna secara meluas dan seiring serta bertukar ganti antara bahasa Melayu dan bahasa Inggeris. Data ini diperoleh melalui paparan dalam penghantaran pesanan ringkas MKN, dan turut diperoleh melalui pemerhatian pengkaji terhadap laman-laman sesawang pelbagai agensi lain yang berkaitan sama ada di peringkat negara atau negeri.Data disaring dan dipilih berdasarkan tanggapan penggunaannya yang difahami oleh khalayak. Jadual 1 menunjukkan 22 akronim yang digunakan secara meluas semasa pandemik COVID-19 ini melanda negara Malaysia. 


\section{Jadual 1}

Akronim Baharu Semasa Pandemik COVID-19

\begin{tabular}{|c|c|c|c|}
\hline Bil & Bahasa Melayu & Bahasa Inggeris & Akronim \\
\hline 1 & Peralatan Perlindungan Peribadi & Personel Protective Equipment & $\mathrm{PPP} / \mathrm{PPE}$ \\
\hline 2 & Prosedur Operasi Standard/Standard Operasi Prosedur & Standard Operating Prosedur & SOP \\
\hline 3 & $\begin{array}{l}\text { Amalkan kerap mencuci tangan dengan air \& sabun, pakai } \\
\text { pelitup muka di tempat awam jika bergejala \& amaran } \\
\text { peringatan dari KKM. }\end{array}$ & Amalkan Wash, Wear dan Warn) & $3 W$ \\
\hline 4 & $\begin{array}{l}\text { Elakkan kawasan yang sesak, sempit dan sembang } \\
\text { dengan jarak yang dekat). }\end{array}$ & $\begin{array}{l}\text { Avoid (crowded place, confined space, close } \\
\text { conversation) }\end{array}$ & $3 S / 3 C$ \\
\hline 5 & Perintah Kawalan Pergerakan & Movement Control Order & $P K P / M C O$ \\
\hline 6 & Perintah Kawalan Pergerakan Diperketatkan & Enhanced Movement Control Order & PKPD/EMCO \\
\hline 7 & Perintah Kawalan Pergerakan Bersyarat & Conditional Movement Control Order & $P K P B / C M C O$ \\
\hline 8 & Perintah Kawalan Pergerakan Pemulihan & Recovery Movement control Order & PKPP/RMCO \\
\hline 9 & Virus Korona 2019 & Corona Virus Disease 2019 & COVID-19 \\
\hline 10 & Kempen "Cegah dan Didik, Amal, Patuh dan Pantau" & - & CAPP \\
\hline 11 & Program Pengurangan Risiko Daerah & District Risk Reduction Program & $D R R P$ \\
\hline 12 & Pusat Pengantaraan COVID-19/Pusat Mediasi COVID-19 & COVID-19 Mediation Centre & PMC-19 \\
\hline 13 & Pusat Pemberian Vaksin & Vaccination Centre & $P P V$ \\
\hline 14 & Sekatan Jalan Raya & Road Block & $S J R$ \\
\hline 15 & Individu dalam siasatan & Patient Under Investigation & PUI \\
\hline 16 & $\begin{array}{l}\text { Pesakit dalam Pemantauan/Individu dalam perintah } \\
\text { pengawasan \& pemerhatian }\end{array}$ & Person under surveillance & PUS \\
\hline 17 & Program Imunisasi COVID-19 Kebangsaan & $\begin{array}{l}\text { The National COVID-19 Immunisation } \\
\text { Programme }\end{array}$ & PICK \\
\hline 18 & Jawatankuasa Khas Jaminan Akses Bekalan Vaksin COVID-19 & $\begin{array}{l}\text { COVID-19 Vaccine Supply Access Guarantee } \\
\text { Committee }\end{array}$ & $J K J A V$ \\
\hline 19 & Bekerja Dari Rumah & Work From Home & $B D R / W F H$ \\
\hline 20 & Pakej Rangsangan Ekonomi Prihatin Rakyat & Prihatin Rakyat Economic Stimulus Package & PRIHATIN \\
\hline 21 & Variant yang membimbangkan & Variant of Concern & VOC \\
\hline 22 & Varian yang perlu diberi perhatian & Variant of Interest & $\mathrm{VOI}$ \\
\hline
\end{tabular}

Untuk mendapatkan pilihan akronim sama ada dalam bahasa Melayu atau bahasa Inggeris, satu borang soal-selidik telah diedarkan. Berikut ialah dapatan kajian.

\section{Jadual 2}

\section{Maklumat Responden}

\begin{tabular}{|l|l|l|l|l|l|l|l|l|l|}
\hline Jantina & Bil(\%) & Umur & Bil(\%) & Kaum & Bil(\%) & Kelulusan & Bil (\%) & Pekerjaan & Bil(\%) \\
\hline Perempuan & 59.2 & $15-20$ & 4.6 & Melayu & 73.1 & Sarjana Muda & 59.9 & Kerajaan & 51.3 \\
\hline Lelaki & 40.8 & $21-25$ & 31.5 & $\begin{array}{l}\text { Bumipute } \\
\text { ra }\end{array}$ & 20.1 & PMR/ SPM/ STPM & 10.5 & Swasta & 3.9 \\
\hline & & $26-30$ & 19.7 & Cina & 3.3 & Sarjana & 10.5 & Pelajar & 33.0 \\
\hline & & $31-35$ & $3.2)$ & Bajau & 0.7 & Penuntut & 9.9 & Pesara & 3.9 \\
\hline & & $36-40$ & 5.9 & $\begin{array}{l}\text { Bajau } \\
\text { Suluk }\end{array}$ & 0.7 & Diploma & 7.2 & Tiada & 7.9 \\
\hline & & $41-45$ & 7.2 & India & 0.7 & Sijil & 1.3 & & \\
\hline & & $46-50$ & 10.5 & Melanau & 0.7 & Doktor Falsafah & 0.7 & & \\
\hline
\end{tabular}

Jadual 2 memaparkan 152 profil dan maklumat responden yang telah terlibat dalam kajian ini. Jumlah keseluruhan yang terlibat ialah seramai 152 orang. Responden perempuan (59.2\%), dan lelaki (40.8\%) Lingkungan umur responden antara 15-20 tahun (6\%), 21-25 tahun (31.5\%), 26-30 tahun (19.7\%), 31-35 tahun (3.2\%), 36-40 tahun(5.9\%), 41-45 tahun(7.2\%), 46-50 (10.5\%), dan 51 tahun ke atas (17.1\%). Kebanyakan repsonden ialah kaum Melayu (73.1\%), Bumiputera (termasuk Bajau, Bajau Suluk, Melanau dan Dusun (22.9), Cina (3.3\%) dan India (0.7\%). Responden yang berkelulusan Sarjana 
Muda/Bacelor ialah sebanyak (59.9), peringkat PMR/SPM/STPM (10.5\%), Sarjana/Masters (10.5\%), masih menuntut (kolej/IPG/IPTA/IPTS (9.9\%), Diploma (7.2\%), Sijil (1.3\%) dan Doktor Falsafah (0.7\%). Rata-rata responden ialah penjawat awam (51.3\%), pekerja swasta (4.0\%), pelajar(32.9\%), pesara(4.0\%) dan belum bekerja (7.9\%).

\section{Jadual 3}

Peratus Pilihan Akronim/Singkatan dalam Bahasa Melayu atau Bahasa Inggeris

\begin{tabular}{|c|c|c|c|c|c|c|c|c|c|c|c|c|c|}
\hline $\begin{array}{l}\mathrm{PPP} / \mathrm{P} \\
\mathrm{PE}\end{array}$ & Bil(\%) & $\begin{array}{l}\text { POS/ } \\
\text { SOP }\end{array}$ & $\begin{array}{l}\text { Bil } \\
(\%)\end{array}$ & $3 W$ & Bil(\%) & $\begin{array}{l}3 S / \\
3 C\end{array}$ & Bil(\%) & $\begin{array}{l}\text { PKP } \\
\text { / } \\
\text { MC } \\
0\end{array}$ & Bil(\%) & $\begin{array}{l}\text { PKPD/ } \\
\text { EMCO }\end{array}$ & Bil(\%) & $\begin{array}{l}\text { PKPB/C } \\
\text { MCO }\end{array}$ & Bil(\%) \\
\hline BM & 81.5 & BM & 2.6 & BM & 2.6 & BM & 32.2 & BM & 57.8 & BM & 80.9 & BM & 78.9 \\
\hline BI & 13.1 & BI & 94.7 & $\mathrm{BI}$ & 90.1 & $\mathrm{BI}$ & 47.3 & BI & 41.4 & BI & 18.4 & BI & 20.3 \\
\hline $\begin{array}{l}\text { Tdk } \\
\text { Pasti }\end{array}$ & 5.2 & $\begin{array}{l}\text { Tdk } \\
\text { Pasti }\end{array}$ & 2.6 & $\begin{array}{l}\text { Tdk } \\
\text { pasti }\end{array}$ & 7.2 & $\begin{array}{l}\text { Tdk } \\
\text { Pas } \\
\text { ti }\end{array}$ & 20.3 & $\begin{array}{l}\text { Tdk } \\
\text { pas } \\
\text { ti }\end{array}$ & 0.6 & $\begin{array}{l}\text { Tdk } \\
\text { Pasti }\end{array}$ & 0.6 & $\begin{array}{l}\text { Tdk } \\
\text { Pasti }\end{array}$ & 0.6 \\
\hline $\begin{array}{l}\text { PKPP/ } \\
\text { RMCO }\end{array}$ & Bil(\%) & $\begin{array}{l}\text { ACCC } \\
\text { /CDA } \\
\text { PP }\end{array}$ & $\begin{array}{l}\text { Bil(\% } \\
)^{2}\end{array}$ & $\begin{array}{l}\text { DRRP } \\
\text { /PPR } \\
\text { D }\end{array}$ & $\begin{array}{l}\text { Bil(\% } \\
)^{2}\end{array}$ & $\begin{array}{l}\text { PM } \\
\text { C- } \\
19\end{array}$ & Bil(\%) & PPV & Bil(\%) & $\begin{array}{l}\text { SJR/ } \\
R B\end{array}$ & Bil(\%) & $\begin{array}{l}\text { PDP/PU } \\
\text { S }\end{array}$ & Bil(\%) \\
\hline BM & 75.6 & BM & 26.3 & BM & 46.7 & BM & 65.7 & BM & 72.3 & BM & 78.9 & BM & 13.1 \\
\hline $\mathrm{BI}$ & 24.3 & $\mathrm{BI}$ & 54.6 & $\mathrm{BI}$ & 37.5 & $\mathrm{BI}$ & 20.3 & $\mathrm{BI}$ & 26.3 & $\mathrm{BI}$ & 13.1 & $\mathrm{BI}$ & 79.6 \\
\hline & & $\begin{array}{l}\text { Tdk } \\
\text { Pasti }\end{array}$ & 19 & $\begin{array}{l}\text { Tdk } \\
\text { Pasti }\end{array}$ & 15.7 & $\begin{array}{l}\text { Tdk } \\
\text { Pas } \\
\text { ti }\end{array}$ & 13.1 & $\begin{array}{l}\text { Tdk } \\
\text { Pas } \\
\text { ti }\end{array}$ & 7.8 & $\begin{array}{l}\text { Tdk } \\
\text { Pasti }\end{array}$ & 7.2 & $\begin{array}{l}\text { Tdk } \\
\text { Pasti }\end{array}$ & 7.2 \\
\hline PICK & Bil(\%) & $\begin{array}{l}\text { JKJAP } \\
\mathrm{V}\end{array}$ & $\begin{array}{l}\text { Bil(\% } \\
\text { ) }\end{array}$ & $\begin{array}{l}\text { BDR/ } \\
\text { WFH }\end{array}$ & Bil & $\begin{array}{l}\text { Vo } \\
\text { c }\end{array}$ & Bil(\%) & VOI & Bil(\%) & PUI & Bil(\%) & $\begin{array}{l}\text { KOVID } \\
19 / \text { COVI } \\
\text { D-19 }\end{array}$ & Bil(\%) \\
\hline BM & 39.4 & BM & 32.8 & BM & 52.6 & BM & 7.8 & BM & 3.9 & BM & 88.8 & BM & 3.2 \\
\hline $\mathrm{BI}$ & 26.3 & $\mathrm{BI}$ & 27.6 & $\mathrm{BI}$ & 47.3 & $\mathrm{BI}$ & 85.5 & $\mathrm{BI}$ & 78.9 & $\mathrm{BI}$ & 9.8 & $\mathrm{BI}$ & 96.7 \\
\hline $\begin{array}{l}\text { Tdk } \\
\text { Pasti }\end{array}$ & 34.2 & $\begin{array}{l}\text { Tdk } \\
\text { Pasti }\end{array}$ & 39.4 & & & $\begin{array}{l}\text { Tdk } \\
\text { Pas } \\
\text { ti }\end{array}$ & 16.5 & $\begin{array}{l}\text { Tdk } \\
\text { Pas } \\
\text { ti }\end{array}$ & 17.1 & $\begin{array}{l}\text { Tdk } \\
\text { Pasti }\end{array}$ & 1.3 & & \\
\hline
\end{tabular}

Jadual 3 memaparkan pilihan akronim yang rata-ratanya berbentuk singkatan yang digunakan semasa pandemik COVID-19 ini melanda negara. Antara 22 akronim yang disenaraikan di atas, dapatan kajian menunjukkan bahawa antara yang paling popular ialah PPP (81.5\%) berbanding PPE (13.1\%), SOP (94.7\%) berbanding POS (2.6\%), 3W (90.1\%) berbanding BM kerana tiada singkatan yang spesifik untuk akronim ini dalam bahasa Melayu dan biasanya dikemukakan secara ayat ringkas iaitu "Amalkan kerap mencuci tangan dengan air \& sabun, pakai pelitup muka di tempat awam jika bergejala \& amaran peringatan dari KKM" -hanya $2.6 \%$ kerana ketiadaan singkatan daripada ayat ini, 35 (32.2\%) dan 3C (47.3\%), PKP (57.8\%) berbanding MCO (41.4\%) PKPD (80.9\%) berbanding EMCO (18.4\%), PKPB (78.9\%) berbanding CMCO (20.3\%), PKPP(75.6\%) berbanding RMCO (24.3\%). Lain-lain akronim seperti VOC (variant of concern) serta VOI (variant of interest) seperti ditunjukkan dalam jadual 3 turut dikemukakan dalam kajian ini kerana secara pemerhatian amat kerap sekali digunakan apabila varian Delta mula dikesan. Kedua-dua akronim ini digunakan secara meluas juga dalam bahasa Melayu sejak akhir-akhir ini.

\section{Kesimpulan}

Dapatan peratusan yang tinggi dalam beberapa akronim dalam bentuk singkatan menunjukkan bahawa kesemua akronim baharu yang digunakan secara berleluasa dikenali dan difahami oleh kebanyakan rakyat Malaysia. Hal ini membuktikan bahawa setiap akronim berkenaan telah diterima pakai dan penyebarannya adalah luas. Akronim, terutama yang berbentuk singkatan dalam dua bahasa iaitu bahasa Melayu 
dan bahasa Inggeris digunakan untuk berbicara tentang perkara yang berkaitan dengan pandemik COVID-19 ini walaupun bahasa komunikasi ialah dalam bahasa Melayu. Jelaslah, kewujudan akronim ini yang rata-rata kebanyakannya berbentuk singkatan telah memperkaya Bahasa Melayu walaupun digunakan secara timbal balik dengan bahasa Inggeris. Oleh itu, melalui kajian ini juga, beberapa ciri akronim yang antara lainnya merupakan singkatan yang terbentuk dengan menggabungkan huruf awal suku kata atau dengan menggabungkan huruf awal dan suku kata daripada satu rangkai kata, dilafazkan sebagai perkataan yang utuh (dalam konteks kajian ini singkatan yang utuh), dapat mengekalkan makna pada rangkai kata asalnya, berfungsi untuk memendekkan sebutan dan membentuk perkataan tunggal telah terangkum dalam penciptaan akronim baharu. Walau bagaimanapun, sesetengah ahli bahasa tidak meletakkan singkatan itu bawah pembentukan akronim. Oleh hal yang demikian, kajian ini telah dapat mengesan bahawa salah satu ciri pembentukan akronim iaitu menggabungkan huruf awal suku kata sangat luas penciptaannya dan lanjutan kajian boleh diteruskan dengan melibatkan lebih ramai lagi responden.

\section{Rujukan}

Abdullah Hassan (2006). Morfologi. Kuala Lumpur: PTS Profesional Publishing Sdn. Bhd.

Baharudin, R., Kasdan, J., \& Shamsuri, A. S. (2020). Covid-19 dalam Korpus Peristilahan Bahasa Melayu: Analisis Sosioterminologi. Journal of Language Studies, 20(3), 221-

241. Capaian dari http://doi.org/10.17576/gema-2020-2003-13

https://www.facebook.com/MajlisKeselamatanNegara/posts/2840199146082973/ (dilayari pada 27 Nov 2020)

https://www.who.int/emergencies/diseases/novel-coronavirus-2019 (diakses pada 11 November 2020).

Kementerian Kesihatan Malaysia. (2020). COVID-19 Malaysia. Dimuat turun daripada http://covid-19.moh.gov.my/ Kronologi COVID-19 di Malaysia. (17 Mac 2020). Berita Harian Online. Dimuat turun daripada https://www.bharian.com.my/berita/nasional/2020/03/666122/kronologicovid19-di-malaysia

Nik Safiah Karim, Farid M. Onn, Hashim Musa \& Abdul Hamid Mahmood (2014). Tatabahasa dewan edisi ketiga. Kuala Lumpur: Dewan Bahasa dan Pustaka.

Raminah Hj. Sabran \& Rahim Syam (1985). Kajian Bahasa. Selangor: Fajar Bakti Sdn. Bhd. 